\title{
Constitutional Politics in Poland: A Report on the Constitutional Committee of the Polish Parliament
}

\author{
Andrzej Rapaczynski†
}

This Article is neither a comprehensive historical account of the work of the Constitutional Committee of the Polish Parliament nor a theoretical synthesis of recent constitutional developments in Poland. Rather, it is a mixture of theory, anecdote, and personal reminiscence that I feel at this point most capable of providing. As will be seen, the work on the new Polish constitution has in some ways been overtaken by events that unfortunately have always lurked in the background of the drafters' work and influenced their decisions. In fact, it is not clear that Poland will enact anything resembling the draft prepared in the process that this Article describes, and it would be premature to attempt a more systematic narration.

My personal perspective also accounts for the Article's focus on constitutional questions of institutional structure. Since February 1990, I have served as an expert adviser to the Subcommittee on Institutions of the Polish Parliament's Constitutional Committee, and both by interests and experience I am best equipped to provide information on the emerging institutional structure of the Polish state. Therefore, this Article does not discuss the protection of individual rights in the next Polish constitution, except insofar as it relates to institutional considerations.

$\dagger$ Professor of Law, Columbia University. I have been an expert advisor to the Constitutional Committee of the Polish Parliament. All the opinions expressed in this paper, however, are exclusively my own. I wish to express my gratitude to the Chairman of the Constitutional Committee of the Polish Parliament, Professor Bronislaw Geremek, for bringing me into the work of the Committee and for listening patiently to what must have sometimes been unwelcome advice. The Chairman of the Subcommittee on Institutions of the Constitutional Committee, Professor Janusz Trzcinski, and other members and experts of the Committee made my work for the Committee an unforgettable, friendly, and cooperative experience. 


\section{BACKGROUND}

A. The Communist Constitution of 1952

Poland still functions under the Constitution enacted in 1952, ${ }^{1}$ even though the political and economic system codified in that document, and even the symbolic name of the state it had introduced (People's Republic of Poland), have been changed. The 1952 Constitution was a product of the first post-war Polish Parliament, dominated by the Communist Party (PZPR). Although it was amended several times, most recently in the fall of 1990, it has been clear since the very moment of Solidarity's victory over the old system in 1989 that Poland must replace the 1952 Constitution-a primary symbol of the communist regime-with a document reflecting the country's democratic aspirations.

Like the People's Republic itself, the 1952 Constitution bears the unmistakable stamp of the Soviet printing press and faithfully reflects the vicissitudes of the history of the socialist bloc. It began with a copy of the so-called Stalinist constitution, the 1938 Soviet model that formally established a fictitiously democratic republic. $A$ naive reader (and there were surprisingly many of them around the world at the time) $)^{2}$ would find little fault with this document: it did not mandate a one-party system, for example, but in fact specifically provided for freedom of association and most of the other political and individual rights typically respected in western democracies. But given the reality of political terror in the country, ${ }^{3}$ the enactment in 1952 of a Polish-language equivalent of the Soviet Constitution was simply a mark of the Soviet conquest and the completion of the Gleichschaltung (putting in the same gear) process after the war.

Surprisingly perhaps, but not really paradoxically, the constitutions of Eastern Europe became somewhat less liberal as the Stalinist terror relaxed. The "leading role" of the communist parties was written into these documents, ${ }^{4}$ as was the special role of

\footnotetext{
1 The most recent version of this Constitution generally available in English translation is Gosbert H. Flanz, Poland, in Albert P. Blaustein and Gisbert H. Flanz, eds, 14 Constitutions of the Countries of the World (Oceana, 1990) ("Recent Constitution"). This translation incorporates most amendments made before December 1989. Unless otherwise specified, all citations to the existing Polish Constitution refer to this version.

2 See David Caute, The Fellow Travellers: Intellectual Friends of Communism (Yale, 1988).

${ }^{3}$ For an account of Poland and other countries during that period, see generally Zbigniew Brzezinski, The Soviet Bloc: Unity and Conflict (Harvard, 1967). For a discussion of the terror of these regimes, see especially id at 85-104, and sources cited therein.

- See, for example, Recent Constitution at 5, Art 3, §1 (cited in note 1). Parliament has
} 
the Soviet Union in the countries' affairs. ${ }^{5}$ The litany of unenforceable social and economic rights expanded with time, ${ }^{6}$ while American-style political rights were scaled down. The introduction of many of these changes in the 1970s and 1980s caused a number of protests in Poland. The constitutionalization of Poland's ties to Moscow and the Warsaw Pact was especially troubling, because it seemed to undermine the very sovereignty of the country.

In a somewhat perverse way, however, the reforms reflected a movement toward the rule of law. The first post-war constitution was a fiction in nearly every respect, and the authorities treated it essentially as propaganda for foreign consumption. As time went by, however, at least two reasons made the ruling elite move toward a more realistic formulation of the basic law as well as of other, more specific legal enactments. First, the Stalinist terror left an indelible imprint on the communist leadership itself: the Party apparatus had, after all, been among the most prominent victims of the great purges. While the communists clearly intended to continue relying on repression as a prime tool of their continuance in power, they apparently concluded that legalizing the repression would protect members of the ruling elites against the most arbitrary and tyrannical abuses of power by the top leadership of the moment. Second, at least in Poland and Hungary, the leadership also tried to present a certain facade of legitimacy to the population at large. The regime made clear that it would tolerate no fundamental assaults on its core powers, but it permitted a certain amount of freedom at the margin. Therefore, the regimes returned in part to legality: at the very least a paper record was left of official action, and the increased publicity deterred most instances of the purely personal exercise of power by the lower echelons of the Party and the state bureaucracy.

To implement such a system, however, legal norms had to become somewhat more realistic; they had to give the leadership the right to suppress opposition to the fundamental principles on which communist authority was based, and with time these changes had to reach the constitutional level. The amendments concerning the "leading role" of the Communist Party, for exam-

since amended this section to end the privileged status of the Communist Party and to guarantee the free formation of political parties. Id at $v$.

- See, for example, id at 7, Art 6, \& 7, cl 2 ("In its policy the Polish People's Republic .. . shall consolidate friendship and cooperation with the Union of Soviet Socialist Republics and other socialist States."). This provision apparently remains in place today.

- See, for example, id at 27, Art 69, 11 (right to "rest and leisure"); id at 28, Art 71 (right to a clean environment); and id, Art 72, § 1 (right to education). 
ple, removed most legal grounds from the potential political claims of the opposition. Similarly, the codification of the dominant position of the Soviet Union and the unassailable status of the Warsaw Pact expressed a formal limitation on Eastern European countries' sovereignty, and thus marked a relatively clear boundary (set by the Brezhnev Doctrine) of all possible internal reforms. At the same time, however, these changes signified that constitutions were beginning to mean something. In Poland the government even took some steps to introduce a watered-down version of judicial review. ${ }^{7}$

\section{B. Downfall of the Communist Regime}

The transition from communism to democracy in Poland took place before the fall of the other regimes in Eastern Europe, and it came about as a result of the so-called Round Table Talks between the communist leadership and the Solidarity-led opposition. ${ }^{8}$ No one originally expected the Round Table agreement to lead to a complete transformation of the old regime. Following the introduction of martial law in December 1981 and the banning of the Solidarity union, the Polish authorities, led by General Wojciech Jaruzelski, largely blunted the ideological communist edge of their power. The government made significant personnel changes at the top, increasing the influence of the military establishment at the Party's expense. The regime also repeatedly attempted to improve Poland's economic situation, and tried to legitimize the ruling elite by presenting it as the true defender of Polish national aspirations and as a buffer between Poland and the forces of Soviet imperialism.

Despite these efforts, the rump communist regime went from one defeat to another. The economy continued to deteriorate, and the regime's attempts to gain a measure of social acceptance basically failed. While its political power was firmly anchored in the military, the ruling elite faced a deepening social and economic crisis. Moreover, the changes in the Soviet Union under Gorbachev made clear that the authorities now had more room to maneuver and could no longer hide behind the threat of Soviet intervention.

7 Id at 18, Art 33a; see also Note, Constitutional Heritage and Renewal: The Case of Poland, 77 Va L Rev 49 (1991).

A A more detailed history of the Round Table Talks and the elections of 1989 is found in Timothy Garton Ash, The Magic Lantern 25-46 (Random House, 1990). See also Wiktor Osiatynski, The Round Table Negotiations in Poland (Working Paper, Center for the Study of Constitutionalism in Eastern Europe, The University of Chicago Law School, 1991) and sources cited therein; Zbigniew Pelczynski and Sergiusz Kowalski, Poland, 9 Electoral Studies 346 (Dec 1990). 
In the end, after some hesitation, the authorities decided to move in the direction of genuine power-sharing. At first, they tried to put together a coalition with the Catholic Church and other nonSolidarity opposition. But when it became clear that Solidarity was too powerful to be left out and that the underground leaders of the union were prepared to make reasonable compromises, the circle around General Jaruzelski resolved to include Solidarity as well.

In the spring of 1989, leaders of Solidarity and the communist regime gathered at the Round Table in order to negotiate their respective roles under the new arrangement. Many Solidarity leaders believed that their only interest lay in the legal reestablishment of the union. In their view, the political compromise essentially benefitted the communists and was a price to be paid for the legalization of the union. Others, however, took the communists' political proposals seriously and worked hard for a bargain that would enable the union to participate meaningfully in the country's political institutions.

What had been seen initially as the stickiest part of the Round Table negotiations, the future status of the Solidarity labor union, was settled quickly and without difficulty. The real wrangling was about the future political structure of the country, and it continued for several weeks. The final political bargain assigned to the communists and their allies (the Peasant Party and two other traditional fig leaves for the communists) 65 percent of the seats in the Sejm, the lower house of the Polish Parliament, with the remaining 35 percent to be filled through genuinely free elections. The compromise further provided for a restoration of the upper house, the Senate, which the communists had abolished after the war. ${ }^{9}$ With all 100 members freely elected, the Senate was to have considerable legislative powers, the most important of which would be a veto on the initiatives of the Sejm, which the latter could override only with a two-thirds majority. A strong presidency would replace the ineffectual old Council of State. While the president would not be the head of government, he would have a veto power similar to that of his counterpart in the United States, and a large measure of control over the army. ${ }^{10}$ The Round Table participants clearly designed that position for General Jaruzelski, who was to become a senior statesman and a guarantor of the compromise vis à vis the Soviet Union. Parliament quickly amended the 1952 Constitution to make the arrangement fully legal.

- Ironically, the communists initiated the idea of the Senate's reconstitution.

${ }^{10}$ Recent Polish Constitution at 14, Art 32, $\$ 2$ (cited in note 1). 
Both sides believed that the compromise guaranteed the communists effective control over the political system, but also gave the opposition a possible veto over communist initiatives. No one had imagined that the election, held on June 4, 1989, would bring such a crushing defeat to the communists that its aftermath would transform the whole Round Table agreement beyond recognition. Solidarity's candidates won, often by huge majorities, all the seats in the Sejm for which they were eligible to compete, as well as 99 percent of the seats in the Senate. In the uncontested country-wide at-large election for the seats in the Sejm reserved for those loyal to the old regime, all but two of the communist-approved candidates failed to receive the required majority of the votes, ${ }^{11}$ with some of the most important communist leaders failing to gain seats. The communists thus could not fill even some of those uncontested seats that the compromise had assigned to them, and they needed the humiliating help of their Solidarity opponents to get their top candidates into the Sejm. The impasse was resolved only by modifying the election rules for the second round of voting; in that round, Solidarity leaders urged their followers to vote for the reform-minded communists on the country-wide at-large list.

Following the election, the communist-led coalition immediately began to crumble. To prevent their own extinction, the exallies of the communists from the Peasant Party and Democratic Alliance began to hint at their availability for a coalition excluding the communists. The communists themselves appealed for a broad-based government. And some influential members of Solidarity began to demand the leadership of the government as a price of their support for Jaruzelski's presidency.

Parliament eventually elected General Jaruzelski President by a humiliating majority of one vote; that the Solidarity leadership engineered the election in order to preserve the Round Table bargain only increased the embarrassment. Shortly afterwards, Jaruzelski designated another communist general, Czeslaw Kiszczak, as Prime Minister, but the latter failed to form a government. A Solidarity-led coalition was becoming inevitable. Finally, in August 1989, Jaruzelski asked Tadeusz Mazowiecki, a Catholic journalist and long-time adviser to Lech Walesa, to form a govern-

12 One of these two candidates apparently passed only because his name appeared last on the electoral list. Voters had to cross out the names of any candidates whom they did not wish to elect. It seems that many voters, intending to cross out all the names on the ballot, drew $x$-shaped lines that did not reach the very bottom of the page. 
ment. ${ }^{12}$ While Mazowiecki invited a few communists to join the new cabinet and gave them control over the army and the police, the Communist rule in Poland was in fact at an end.

\section{Beginnings of the Current Constitutional Reform}

The new Solidarity-led government soon proposed a series of constitutional amendments to provide the necessary legal basis for the functioning of democratic institutions. Adopted in December 1989, these amendments eliminated the constitutionally privileged role of the Communist Party, introduced the principle of the equality of diverse forms of ownership (thus providing a constitutional foundation for private property and the emerging market economy), and established a number of house-cleaning measures, enabling the new authorities to initiate the political reconstruction.

From the beginning, however, the amendments to the 1952 Constitution were intended to be temporary, and no effort was made to transform the old document into a permanent basic law of the newly free Poland. In particular, no attempt was made to change the hackneyed communist phrases of the bill of rights in the old Constitution ${ }^{13}$ to express the true aspirations of the new democratic order, even though some of the old provisions concerning the social and economic regime clearly contradicted the new emphasis on a market economy. ${ }^{14}$ Everyone understood at the time, however, that the 1952 Constitution would soon be replaced by a new document establishing the legal foundation of democratic governance.

In accordance with these expectations, in early 1990 the Sejm appointed a special Constitutional Committee, charged with the task of preparing the new constitution. Chaired by one of the most important Solidarity leaders, Professor Bronislaw Geremek, the committee was in turn divided into three subcommittees: the Subcommittee on Institutions, charged with designing a new govern-

\footnotetext{
12 Ironically, Mazowiecki had been one of the Solidarity leaders who did not believe in the significance of the political compromise during the Round Table negotiations. He was active in the negotiations for reinstatement of the union but, following the election (in which he refused to run), he wrote an article decrying as irresponsible the call for a Solidarity-led government. Once in the government, however, Mazowiecki quickly moved to consolidate his power and independence, and his king-maker, Lech Walesa, soon regretted his nomination.

1s Recent Constitution at $26, \mathrm{Ch} 8$ (cited in note 1 ).

14 Thus, Article 68 still refers to "the socialist economic systems" and central planning, while the new Article 6 guarantees "freedom of economic activity without regard to the form of ownership."
} 
mental structure; the Subcommittee on Human Rights, charged with the preparation of a new bill of rights; and the Subcommittee on Social and Economic Provisions, charged with preparing the articles dealing with property, labor relations, and the new economic order. The committee also appointed a number of expert advisers (myself among them) for each subcommittee.

In the early stages of the Constitutional Committee's work, the committee met in plenary sessions to discuss matters such as the general tenets of the new constitutional order, the relation between Polish domestic law and the norms of international law, and the basic types of individual rights to be included in the constitution. Subcommittees met to discuss the more technical issues within their jurisdiction and further delegated the bulk of the drafting to individual experts or groups of experts.

As of this writing, the full Constitutional Committee has discussed section-by-section the proposals drafted in the subcommittees. The original plans called for the committee to make further revisions to the draft and then present the constitution to a joint session of both houses of Parliament (which passed a special law to this effect), ${ }^{15}$ followed by a national referendum.

While these plans have never been officially revoked, the political situation in Poland has changed dramatically, and the fate of the draft is uncertain. From the very beginning, the Sejm's Constitutional Committee was a subject of considerable controversy. The Round Table Sejm was not, and still is not, a product of fully free elections. As a result, the Senate, with a sense of its greater representativeness, formed its own Constitutional Committee and began working on a separate draft, even though the Constitution of 1952 placed the matter of constitutional changes in the Sejm. ${ }^{16}$ The Senate committee has not played a large role, because no party leaders (including Solidarity's) approved of its formation; its drafts have not received serious attention. Consequently, the Sejm Committee has managed to retain its predominant position. Yet, repeated attempts to form a joint committee of both houses have also failed, and the very lack of a clear commitment on the part of the Senate to the work of the Sejm's committee has cast some shadow on the Sejm's work.

The composition of the subcommittees also gave some grounds for concern. Solidarity deputies, who provided the impetus behind

\footnotetext{
15 See note 19.

${ }^{16}$ Recent Constitution at 35, Art 106 (cited in note 1). This has been changed in the meantime. See note 19 .
} 
the project of a new constitution, dominated the Constitutional Committee as a whole. Strangely enough, most of these deputies had little interest in the overall institutional design that would emerge from the drafting. Many of them were veterans in the struggle for human rights, and they flocked to the subcommittee charged with preparing the new bill of rights. Others had strong ideological commitments to the free market and the dismantling of the command economy, and they chose to join the Social and Economic Provisions Subcommittee, although its work was of necessity limited to a few articles in the new constitution.

Unelected deputies tied to the old regime therefore came to dominate the Subcommittee on Institutions, charged with drafting the core of the new document: the sections dealing with the parliament, the government, ${ }^{17}$ the presidency, and the judiciary. Moreover, most experts attached to the Subcommittee on Institutions also had strong ties to the old regime, partly because the subcommittee members did and partly because most Polish experts in the area came from the once-tightly controlled university law faculties. Even with the addition of two expatriate experts clearly associated with the new regime, the Solidarity parliamentary leadership had good reason to be concerned about this crucial subcommittee. ${ }^{18}$

Other factors combined to weaken the Sejm Committee even further. With its communist deputies and their erstwhile allies occupying 65 percent of the seats, the Sejm obviously could not give full expression to the political will of the Polish people. Nevertheless, in the initial stages of its work, the Sejm had more legitimacy than one might expect in part because the communists very quickly became demoralized. In addition to the crushing defeat in the parliamentary elections, events in the region (above all, the disappearance of a realistic Soviet threat) made the communists' role as the facilitators of the transition no longer credible. The communists proceeded to dissolve their party, and individual communist deputies scrambled to join the ranks of the democratic movement. The parties previously allied with the communists (the

17 I use "government" here, and elsewhere in the Article, in the sense in which the term is commonly used in parliamentary systems: to refer to the prime minister, the cabinet ministers (typically also members of parliament), and the departments they head, and not to the entire governmental structure.

18 This concern turned out to have been quite unnecessary. Experts and a few selfselected deputies did the bulk of the subcommittee's work, and the Polish experts' communist loyalties turned out to be superficial. Following the demise of the communists as an organized force, these experts had no ideological axe to grind and worked quite harmoniously to produce the best possible draft under the circumstances. 
Peasant Party, above all) have similarly transformed themselves in order to fit into the new democratic order. In some sense, then, the Sejm became much more representative than one could have expected.

Paradoxically, one could perhaps even venture the claim that the Sejm was more representative than if the elections had been entirely free. Compare the composition of the Sejm with that of the Senate, where the duel between Solidarity and the communists allowed the union to sweep 99 percent of the seats. The Senate thus became a one-party institution, which included no genuine representation of the peasants or any of the social democratic or other leftist formations that exist in other European countries. The unelected members of the Sejm not only introduced some variety into its composition, but they also tried to behave in a responsible fashion: the dubious legitimacy of their position made them exercise great care in opposing the Solidarity-dominated government and its parliamentary leadership, at least so long as the latter was itself united and basking in the glow of popular approval.

As time went by, however, the legitimacy of the Sejm was gradually tarnished, not least because the Solidarity movement began to split between a group based in Gdansk, centered around Lech Walesa, and a group based in Warsaw, composed primarily of intellectuals who came to dominate the government. Clearly resenting the attempt of his erstwhile advisers to keep him at arm's length from the center of power, Walesa himself began a bruising campaign against what he presented as an alliance between the compromised ex-communists and the "leftist" intellectuals in the government. Among other things, Walesa attacked the very idea that the Round Table Parliament could legitimately enact a new democratic constitution.

The Solidarity parliamentary leadership knew that the Round Table Sejm was not an ideal body to adopt the new constitution. At the same time, they felt that the Sejm, perhaps in part because many of its members knew that they held their seats by historical accident and should "redeem" themselves by good behavior, might actually be more cooperative than the next, democratically elected body, given the absence of a developed party system and the likely combination of inexperience and anarchic enthusiasm among the new deputies. (The unruly Senate was, again, quite instructive in this respect.) As a result, the Solidarity leadership in Parliament (firmly in the hands of the Warsaw group) decided quite early on a strategy for drafting and adoption of a new constitution. This strategy called for the Round Table legislature to prepare and vote 
on the new constitution. Then, in order to heighten the document's legitimacy, Parliament would submit it to a national referendum. ${ }^{19}$ Furthermore, the leadership contemplated that the next parliament, then expected to be elected in the spring of 1991, could offcially promulgate the new constitution, preferably on the symbolically important date of May $3,{ }^{20}$ without, however, being given an opportunity to change a document already approved by the people themselves.

The parliamentary leadership also saw the new constitution in a more directly political perspective. The forces behind Walesa demanded that General Jaruzelski resign or be removed from the presidency, to be replaced by someone more representative of the new order. The Gdansk group felt that the new president must be Lech Walesa, and the people around Walesa were probably prepared for his election by the Round Table Parliament. But the Warsaw group believed that it could field a candidate who would beat Walesa in a popular election, ${ }^{21}$ and therefore pushed through Parliament a law providing for direct election of the president.22 Having done this, the Warsaw leaders quickly saw that the Gdansk electrician would be much harder to beat than they had expected, and soon had to reckon with the likelihood of a powerful Walesa Presidency. Walesa made no secret of his intention to be an active president. The Solidarity leadership in Warsaw began therefore to look to the new constitution as potentially a very effective instrument for preventing Walesa's future dominance over Parliament

\footnotetext{
19 Parliament formalized this strategy in a statute passed in the fall of 1990 , specifying that the two houses of Parliament sitting together as a "National Assembly" must approve the new constitution by a two-thirds majority and then submit it to a referendum. While technically the referendum would be non-binding, the new constitution would clearly derive much of its legitimacy from the direct popular approval.

${ }^{20}$ The first Polish Constitution was adopted on May 3, 1791. According to some reckonings, the May 3 Constitution (as it came to be known) was the first European constitution, and it is a symbol of the Polish Enlightenment. As of this writing, it is clear that the new parliament will not be elected by the time of the bicentennial (with the election scheduled to take place in October 1991), but the Round Table Parliament might still choose the date of May 3, 1991, as the official publication date of the results of the work of its Constitutional Committee.

"1 A number of politicians associated with the Warsaw group were, at the time, riding high in the polls, while Walesa, with his habit of speaking before thinking, appeared less and less popular. Shortly after the decision to go to a direct election, however, the winds began to shift, and Walesa started to gain ground against the "Warsaw" candidate, Prime Minister Mazowiecki.

${ }^{22}$ Walesa's backers could hardly oppose the call for a popular election, after their attacks on the legitimacy of the Round Table Sejm. The role reversal was nearly complete: the Warsaw group in principle preferred an indirect election.
} 
and the government. ${ }^{23}$ In response, the forces around Walesa became even more strongly opposed to the work of the Sejm committee and considered it ever more a symbol of an unholy alliance of old and new elites. The legitimacy of the Sejm committee's work, which could remain broadly acceptable only if viewed as expressing the ideas of a unified Solidarity leadership, lost support from a large segment of the public.

Other aspects of the Constitutional Committee also became politicized to a degree hardly compatible with proper consideration of the long-term interests of the country. The question of whether to include the basic principles of the electoral system in the text of the constitution, as well as which electoral system to adopt, came to be seen as largely a matter of party interest, rather than longterm considerations. A number of unelected deputies tied to the old regime viewed an extreme system of proportional representation as their best hope for preserving a niche for themselves in the new political order. Similarly, the questions of abortion and the separation between church and state became matters of intense controversy, in which immediate political gains or losses seemed to play as prominent a role as any deeper constitutional convictions. ${ }^{24}$

The December 1990 presidential election cast the greatest doubt on the work of the Constitutional Committee. Lech Walesa won handily, while the Warsaw group's candidate, Prime Minister Mazowiecki, failed to qualify for the second round, ${ }^{25}$ suffering an embarrassing defeat at the hands of a shady expatriate virtually unknown only a few weeks earlier. Both the new president and the people around him made it abundantly clear that they intended the focus of power to shift from the prime minister's office to the

\footnotetext{
${ }^{23}$ This is not to say that the Warsaw leadership acted in a purely opportunistic fashion; its opposition to a strong presidency was also grounded in principle.

${ }_{24}$ The matter of church-state relations illustrates the predominance of immediate political concerns. In August 1990, two weeks before the beginning of the school year and without any prior consultations with Parliament, the government issued a regulation introducing religion in public schools, despite the fact that public opinion polls had indicated that most parents opposed the move. Apparently, however, the government had been under intense pressure from the Church and decided to settle the matter before the upcoming presidential elections. The government's calculations may have been correct, in that the public mood shifted rather quickly in favor of the change once the decision had been made, and the matter was removed from the election campaign. But very little attention seems to have been paid to its long-term consequences on the separation of church and state.

${ }^{25}$ To be elected, a candidate had to obtain an absolute majority of the vote. If no candidate received the required majority in the first round, the two candidates with the greatest numbers of votes were entitled to take part in a run-off election. Walesa polled twice as many votes as the next candidate in the first round (Stanislaw Tyminski), but failed to win outright. In the second round, he won close to 80 percent of the vote.
} 
Presidential Palace. Sensing the diminution of the office, several people refused Walesa's offer of the post of prime minister, and the person who ultimately accepted it (Jan Krzysztof Bielecki) was a relatively obscure man without any political base of his own. At the same time, a kind of shadow government began to form around the new president. These developments undoubtedly reduced the chances that the draft prepared by the Constitutional Committee will eventually become the new constitution. The people around Walesa had long argued that the Round Table Sejm did not have sufficient legitimacy to adopt a new constitution, and the draft (prepared under the leadership of people tied to Walesa's opponents) limited the power of the president to an extent presumably unacceptable to the new establishment.

Still, neither Walesa nor Parliament has officially repudiated the work of the Constitutional Committee. Indeed, in the first few weeks after Walesa took office, the Constitutional Committee continued its work, until a reasonably complete draft had been prepared, and then shifted its attention to the matter of the new election ordinance. Moreover, the draft constitution has not, at the time of this writing, become subject to the intense criticism one might have expected. Equally surprising, President Walesa, faced with a need to assure that his first months in office are not punctuated by a series of important elections and concomitant shifts in government policy and personnel, began to hint that the term of the Round Table Parliament may be extended (perhaps by as much as a year) beyond the spring of 1991 .

Thus, once again, the roles have reversed. The Walesa camp, which had come to power with the help of its demand for a political "acceleration" that would eliminate the remnants of the communist regime from positions of authority, seemed to be planning an extension of the Round Table Parliament's term of office beyond anything that the allegedly foot-dragging Warsaw group had in mind. After a few weeks, the Walesa camp changed course again and proposed May 26 as the date of the new elections, but in the absence of a consensus on the new election law, this date was unrealistic. $^{26}$

This jockeying for position has left the Constitutional Committee in limbo. Its leadership remains largely in the hands of the Warsaw group, and there is a certain momentum in its commitment to the draft the experts and the subcommittees have pre-

\footnotetext{
28 The new election is now planned to be held in October 1991.
} 
pared. But it has also become clear to most people that the new constitution will have to wait until the next parliament. As of this writing, it is impossible to predict what will happen. It is difficult to imagine, however, that the present draft will indeed become the new basic law without major changes, although it is also not clear how public opinion will react to changes introduced because of narrow political considerations. ${ }^{27}$ For this reason it may be unwise, except for a few special cases, to discuss in detail the particular provisions of the draft now under consideration. The process of preparing the new constitution, with its peculiar mixture of longand short-term considerations, and the general substantive concerns raised in the work of the Constitutional Committee may nonetheless have significance beyond this draft and beyond the Polish situation.

\section{The Nature of the New Constitution}

One of the most basic questions concerning the new Polish constitution was whether it would be primarily a legal norm rather than a political or symbolic document. This question, never explicitly discussed by the Constitutional Committee, colored a number of discussions concerning the individual rights provisions and the institutional model of the new political system. In this Part I examine three basic aspects of the emerging Polish constitution: judicial review, positive and negative rights, and amendment procedures. The three examples give a flavor of how the drafters viewed the nature of the new Polish constitution.

\section{A. Judicial Review}

Most European countries, including Poland, have historically viewed their constitutions as primarily symbolic, uniting the people behind certain principles by which the state was morally and politically obliged to be guided, but which did not function as legal norms in the American sense. ${ }^{28}$ In particular, while the courts would consider constitutional provisions when interpreting various aspects of the law, traditionally they were not supposed to enforce the constitution by striking down conflicting normative pronounce-

\footnotetext{
${ }^{27}$ The most obvious example would be a strong shift toward a more presidential regime that could be viewed as tailored to satisfy Walesa's appetite for more power.

${ }^{28}$ See generally Rubio Llorente, Constitutional Jurisdiction in Law-Making, in Alessandro Pizzorusso. ed. Law in the Making: A Comparative Survey 156 (Springer-Verlag, 1988).
} 
ments of the political organs of the state. Constitutions set the institutional framework of the state and defined the identity and the aspirations of the people in their sovereign capacity. European constitutions thus typically still contain many hortatory statements and confer rights that courts do not directly enforce.

Since World War II, many European countries have modified this tradition by adopting some form of judicial review, and this trend has led to an increased understanding of the constitution as the basic law of the land. In fact, the shift toward some form of judicial control over the political process had reached Eastern Europe even before the upheavals of 1989, and the communist authorities in Poland experimented with limited judicial review. ${ }^{29}$

The new democratic leaders of Poland had additional reasons to look to the United States and those Western European countries that had adopted the model of judicial enforcement of constitutional norms. In their struggles with the communist regime, the opposition repeatedly pointed out the contrast between the constitutionally guaranteed freedoms of citizens and the niggardly embodiment of those freedoms in ordinary statutes and routine law enforcement, as well the absence of a truly independent judiciary to curtail abuses of power by the government. As a result, everyone involved in the process of drafting the new constitution assumed that the new document would feature rather prominently some form of judicial review, including the possibility of a judicial invalidation of legislative enactments.

Poles both inside and outside the Constitutional Committee considered several models of judicial review. ${ }^{30}$ One possibility was the American model, in which every judge (state and federal) has the power to declare all official actions, including legal enactments of the national legislature, void because of their unconstitutionality. This model is often viewed as peculiar to the common law tradition, and many people involved in the work of the Sejm committee considered it ill-suited to Polish conditions. Some believed that ordinary Polish judges did not have enough training to exercise such great power, nor could they get adequate training within a reasonable amount of time. Others believed that the American system was unsuited to the civil law tradition, because the civil law judge (essentially a professional civil servant) lacks the prestige and experience of the common-law judge, or because the civil law

20 See Note, 77 Va L Rev 49 (cited in note 7).

so For a general discussion of judicial review in a comparative context, see Mauro Cappelletti, The Judicial Process in Comparative Perspective (Clarendon, 1989). 
is too specialized (which, however, is not really true in Poland). I have never fully shared some of these criticisms, but the committee never seriously considered following the American model in detail. Some members of the committee were inclined, however, to follow the American system of combining the power of judicial review with the other competencies of the existing Supreme Court, rather than creating a separate tribunal to deal exclusively with constitutional matters.

Another model was the German one. In Germany, a special Constitutional Court, endowed with the unique power to invalidate ordinary legislation incompatible with the provisions of the Constitution, has exclusive jurisdiction over constitutional cases. ${ }^{31}$ While most Polish specialists favored this model (for which some domestic precedents already exist), there was considerable anxiety that the German procedure of "individual complaint," by which any private person may test the constitutionality of legislation, would lead to a flood of frivolous litigation that could ultimately undermine the whole institution of judicial review. Those who voiced such fears preferred to limit constitutional review to cases in which certain specified actors (such as legislators or the president) bring their complaints before a constitutional tribunal, or in which lower court judges refer to the same tribunal those constitutional questions essential to the resolution of cases before them.

The Subcommittee on Institutions ultimately chose the German model, and wrote a draft that allowed various official actors, as well as private individuals, to bring their complaints before a special Constitutional Tribunal. ${ }^{32}$ The Constitutional Tribunal would be empowered to issue so-called "abstract opinions" (opinions issued, for instance, by request of the president, that are nevertheless binding) but would not issue advisory opinions, nor could it be asked to confirm a law's constitutionality. At the same time, the draft proposes to follow the French system by separating judicial review of legislation from the review of the legality of executive and administrative action, vesting the latter power in a special Administrative Tribunal.

31 For the Basic Law, see Gisbert H. Flanz, The Federal Republic of Germany 75, Art 93, in Blaustein and Flanz, eds, 6 Constitutions of the Countries of the World (cited in note 1).

32 This text has not yet been translated. 
B. Negative and Positive Rights

Despite these differences concerning the form of judicial review, one might think that the fact that some version of judicial review was taken for granted would settle the question of the symbolic or aspirational versus legal nature of the constitutional text. This was not the case, however, for the drafters faced strong political pressures to include in the constitutional text a number of provisions not readily judicially enforceable.

If a constitution is to be essentially a legal document, it must primarily include provisions that courts can enforce without upsetting the proper balance of power among the branches of government in a democracy. It is usual, of course, for a constitution as a legal document to include all kinds of political rights and a number of other so-called "negative rights," which prevent the state from interfering with an individual's exercise of free speech or religion or limit the state's power in criminal proceedings. But it is often also believed that a constitution must be very sparing in guaranteeing so-called social and economic rights, such as the right to work or to decent housing, or the right to a clean environment. It might be difficult for a court to insure that the government observes rights of this kind without taking on the role of a superlegislature, reallocating resources and reshuffling governmental priorities to a degree that healthy democratic systems ordinarily reserve for the legislature and executive. The provision of such entitlements usually requires the state to make substantial budgetary outlays, as well as a host of other decisions concerning the relative importance of various social concerns, such as full employment versus inflation, or spending on housing versus spending on education or defense.

Courts generally do not have the competence to make such decisions: neither their training nor the forum of litigation provides them with the information and expertise required to structure governmental affairs at this level. Nor do courts have the legitimacy-that is, the democratic pedigree-to make their decisions palatable to the public, who must live with the consequences. Social rights are important; indeed, their achievement may be one of the most basic functions of a constitutional democracy. But the hard choices necessary to turn rights into realities are often thought to be better left to the political system, rather than legally binding provisions of the constitutional text.

Considerations of this kind became very important in the Polish context. First, Poland has a long tradition (antedating the 
communist regime) of governmental paternalism, including largescale government intervention in the economy. Furthermore, while Poland's new leaders rejected much of the communist rhetoric along with the communist regime, the Polish population's commitment to the free market may prove rather shallow. The Poles have had no experience with unemployment during the last forty years and economic inequality, although present, was always both hidden and officially disparaged under the communists. Finally, the present government had its origins in union activity; its enthusiasm for an unadulterated form of capitalism is tempered by a concern that the government's most powerful political constituency might not tolerate the resulting dislocations.

The drafters thus felt a significant pressure to retain some form of constitutional commitment to full employment, or at least to express an obligation of the state to extend special protection to labor. On the other hand, as the opponents of the right to work have pointed out, economic restructuring will inevitably produce relatively severe unemployment. A right to work, even if in principle enforceable as a matter of constitutional norms, could not be judicially (or otherwise) enforced in Poland until this restructuring is largely completed. Consequently, opponents have argued, including this right in the basic law would make the constitution into a symbolic and aspirational document rather than a genuine legal norm.

The right to work exemplified a more general problem. Communist Poland had an extensive system of laws and constitutional provisions protecting the rudimentary welfare of the workers: free (if miserable) health care $^{33}$ paid vacations, ${ }^{34}$ maternity leaves, ${ }^{36}$ and state retirement pensions, to cite a few examples. The drafters initially had to decide how much of this system should be constitutionalized in the future. To the extent that they chose to protect these social and economic rights through the constitution, the drafters then had to decide whether to guarantee a large number of very specific rights or to use sweeping and majestic phrases that would later acquire meaning through judicial interpretation.

The Subcommittee on Social and Economic Provisions has found this problem particularly difficult and as of this writing has not produced its final proposals. The draft that is likely to emerge,

\footnotetext{
ss Recent Constitution at 28, Art $70, \S 2$ (cited in note 1 ).

s4 Id at 27, Art $69, \S 2$.

ss Id at 29, Art 78, $\S 2$, cl 2. The same Article provides more general and sweeping guarantees of equality for women.
} 
however, will probably eschew the most explosive commitments, while stating a number of vague (and presumably not readily enforceable) aspirations. It is proposed, for example, not to guarantee a right to work, but to oblige the state "to protect labor." There are also proposals to constitutionalize a number of specific rights, such as minimum wages or maximum hours, which courts could enforce without crippling the economy.

\section{The Amendment Procedure}

A final issue that illustrates the nature of the constitution is the amendment procedure. Strangely enough, the drafters have neither prepared nor extensively discussed the text of any possible procedures for amending the document they are writing. Some voices have urged that the new draft should follow the tradition of making constitutional amendments relatively easy: under the old Constitution, a two-thirds majority of the Sejm can amend the document..$^{36}$ Others have argued, however, that the new constitution should have more permanence: according to this view the drafters should strive to initiate a new tradition, influenced by the American model, in which the basic law would function as a focal point of the national and political identity of the Polish people.

Proponents of a relatively easy amendment procedure have pointed to the danger of entrenching a document that may hamper future development and ultimately weaken the new political order by taking away much of its flexibility. Proponents of a more difficult procedure note the need for strong protection of individual rights and a lasting nonpartisan commitment to the basic institutional structure. They accordingly have proposed that the requirement of a two-thirds majority be strengthened by the added requirement of a national referendum whenever a sufficient number of parliamentary deputies so desire. While the discussion has not been extensive, the intermittent intrusion of narrow political concerns into the drafting process has significantly weakened the position of those who argued for a deeper entrenchment of the norms being prepared under such circumstances; the ultimate document is likely in large part to reflect shifting political considerations.

\section{The Electoral System}

A crucial aspect of the political order of the future Poland-indeed, one that may more than any other determine the

\footnotetext{
ss Id at 35, Art 106.
} 
fate of democracy in Eastern Europe's largest country-is often not dealt with in written constitutions: the nature of the electoral system used to fill the seats in the national legislature. Although the new Polish constitution will also probably leave this matter to ordinary legislation, the electoral system was part and parcel of the recent constitutional debates in Poland. The very fact that Parliament conferred the task of drafting the electoral law to the Constitutional Committee underscores the significance of this issue.

One may approach the electoral problem in two related ways. The first is to look at it in pragmatic or empirical terms: depending on the electoral system one chooses, one can readily predict that certain groups will acquire greater or lesser ability to shape the legislative process. To the extent that the executive depends on the outcome of legislative elections, these groups will also have greater or lesser ability to determine the outcomes of the political process as a whole. The second way is to consider the issue in more lofty terms: by determining the way in which the nation chooses its representatives, the electoral system defines the very concept of democracy, the way in which the political institutions are related to the source of their own legitimacy.

Eastern Europeans are much more likely to consider the issue in the latter terms. To be sure, their more narrow partisan interests sometimes track their ideological pronouncements, and a western observer may take their rhetoric with a grain of salt. Thus, for example, the communist epigones stand little chance of winning an outright majority in any electoral district and are also among the most ardent proponents of proportional representation, which may assure them of some seats despite their inability to get more than a few percent of the national vote. Nevertheless, the Eastern Europeans' commitment to the discourse of principles goes beyond a calculation of party interest: in fact, it often contradicts the latter, expressing a certain disdain for (and often ignorance of) an "engineering" approach, which looks at practical consequences before delving into a discussion of abstract ideas. This tendency to stay at a relatively high level of abstraction sometimes results in a certain formalism: generalities such as the "sovereignty of the people" or "separation of powers" or a number of Latin rules and taxonomies often take precedence over hard-headed pragmatic considerations.

An example from the work of the Constitutional Committee will illustrate this point. As explained earlier, the Round Table negotiations preceding the communist departure from power resulted in a complex compromise to assure the opposition some meaning- 
ful form of participation while still preserving the core of communist control. ${ }^{37}$ The main element in this compromise was the restoration of the Senate, in which the opposition could freely compete for seats with the communists. But the opposition centered around Solidarity dealt such a decisive blow to the communists and their allies in the first elections that Solidarity was able to form a broadbased government under its own leadership.

The restored Senate thus lost most of its raison d'être from its very beginning. To be sure, its symbolic legitimacy provided a certain balance to the still largely unelected Sejm, but at a significant price: it raised the specter of legislative paralysis. The Round Table negotiators had designed the Senate to function as a Solidarity veto instrument. The Senate could not only initiate its own legislation but could also propose amendments to the laws put forth by the Sejm. Unless the Sejm agreed to these amendments or rejected them by a two-thirds majority, the law could not go into effect. This arrangement turned out to be very cumbersome. The legislators lost considerable time trying to synchronize the work of the two houses, and this, together with the lack of party discipline among the senators, significantly slowed the legislative process just when the government was trying to overhaul the foundations of the Polish state.

All the drafters of the new constitution therefore understood that the institution of the Senate could not remain unmodified. Yet they also knew they could not abolish it: the Senate would have to vote on the new constitution, and as a symbol of Solidarity's victory it enjoyed considerable popularity among the Poles. The trick was to find some way to keep it and not to make it entirely insignificant, but also to prevent a legislative stalemate in the future.

The Subcommittee on Institutions proposed to solve this dilemma by providing for indirect election of senators and making the Senate into an organ representing the units of the newly created local government. In this way, the Senate's considerable prestige would strengthen the democratic principle of local autonomy, while the diminished personal stature of the senators would make it easier for the party leaders to control them.

During discussion of this proposal at a plenary session of the Constitutional Committee, a British expert adviser of Polish extraction $^{38}$ raised the following point. The purpose of local govern-

37 See Part I.B.

ss Professor Zbigniew Pelczynski of Oxford University. 
ment reform, which Parliament had put into effect sometime before, was to create many small, autonomous districts, each of which could decide important local matters with extensive citizen initiative and participation. In planning these local districts, no one had thought about using them as a springboard for national representation; all that had been at issue was to calibrate local governments to their communities. Thus, the average rural district naturally came to be much smaller than the urban one, and the proportion of districts dominated by rural interests was much greater than the proportion of rural inhabitants in the country as a whole. If these local districts were now to become the basis for representation in the Senate, the adviser pointed out, the Senate would become the most potent rural lobby in existence, representing the interests of "provincial Poland" in a way that the drafters most likely had never intended.

No one on the committee had thought about this consequence before the adviser pointed it out. Even more surprisingly, no one paid much attention to the adviser's point even after he made it: committee members simply mustered no interest in such Realpolitik. ${ }^{39}$

\section{A. The Polish Preference for Proportional Representation}

From the beginning, the Constitutional Committee considered the development of laws governing the election of the more important Sejm to be among its principal tasks. The old electoral ordinance, giving an artificial majority to the communists and their allies, could not provide the basis of the next election. It was thus necessary to prepare a new ordinance before the end of Parliament's term, regardless of the progress of work on the constitution.

The drafters faced a basic choice between some version of proportional representation and what the Poles call a "majoritarian" system, which requires the winning candidate to obtain at some point in the process a plurality or majority of the votes cast. Most of those who expressed an opinion felt that only a system of proportional representation was truly democratic, although the majoritarian system (especially its French version, which requires

\footnotetext{
so The matter was ultimately considered by the experts who produced the final draft. The principle of tying the election of senators to the local units of self-government was preserved (with the vote being given to all local councilmen), but representation was made proportional to the population of each district. In addition, the Senate was given a right to amend legislation (without any additional approval by the Sejm), but the Sejm was given the power to reject the Senate's amendments by the majority of 11/20.
} 
an absolute majority and provides for a two-round election where necessary to accomplish this goal) had some proponents. A number of reasons were given for this preference for proportional representation, ranging from appeals to tradition to a rather confused belief that proportional representation better protects the interests of the minorities. ${ }^{40}$ But the most basic source of the preference, which some groups expressed despite a potential party interest to the contrary, was a certain vision of democracy or, more precisely, of the idea of representation.

Proponents of proportional representation essentially argued that it better expresses the will of the electorate. This argument assumes, in turn, that we should understand representation quite literally, as a faithful reflection (re-presentation) of the constellation of political forces in society. Social groups sharing a common interest or agreeing on a vision of the public interest should be able to organize in political parties of their own, and these parties should then be given a chance to represent them in Parliament. The legislature would then constitute a microcosm of society; each significant social group would have its own voice.

Going one level deeper in the analysis of the Polish preference for proportional representation, one can discern in it a certain view of the relation between the government and the governed. According to this view, which is common in continental Europe, the people are the true "sovereign," endowed with a will of their own from which all legitimate political authority stems. A legitimate government must thus be grounded in a legislature that is really of the people in the very strong sense of the identity of the rulers and the ruled. This identity guarantees against governmental repression and ensures that citizens are truly free (that is, following their own will) in obeying the laws of their country. ${ }^{41}$ Only when the parliament contains all the essential ideological ingredients that make up the nation as a whole is the soul of the people present in its pronouncements. Legislation emanating from such a parliament wears the mantle of democratic legitimacy.

One can make many arguments against this account of democratic legitimacy. The objection raised most often in Poland was

40 There is no a priori reason to believe that proportional representation better protects the interests of minorities. As I argue below, the relevant difference simply concerns the point in time at which minorities can bargain for concessions with the other groups comprising a potential majority.

41 The philosophical underpinnings of this conception of popular democracy, which came to the fore during the French Revolution, had been provided by the work of JeanJacques Rousseau and further developed by Immanuel Kant. 
essentially pragmatic: proportional representation will lead to an excessive fragmentation of political life, with the concomitant danger of weak, revolving-door governments, ultimately leading to anarchy. Such a danger is particularly great in a country in crisis, with an acute need for a strong and decisive government. This argument did not sway the proponents of proportional representation. It seems that the Poles, having achieved freedom after so many years of struggle, could not take seriously the idea that the choice of one electoral structure over another could threaten the long-term health of democracy. Advocates of a proportional system felt that greater diversity could only strengthen Parliament's legitimacy, while limiting it might give rise to the unhealthy and muchfeared phenomenon of extra-parliamentary opposition.

Those who acknowledged some strength in the anti-fragmentation argument simply responded by proposing a limitation on the size of electoral districts ${ }^{42}$ or the institution of a threshold (such as 5 percent of the vote) that a party would have to achieve before gaining representation. But interestingly enough, the more theoretical arguments against the concept of democracy underlying proportional representation were neither commonly made nor well received. It was rarely pointed out, for example, that the idea of the "identity" of the popular will with the products of a representative legislature is riddled with theoretical difficulties, stemming from the fact that no aggregation of individual (or group) preferences into a single social choice is in principle free from paradoxes. ${ }^{43}$ It was also rarely noted that the assumption of the possible identity of the people with its representatives flies in the face of the oftrepeated allegiance to the ideas of liberalism. Most liberals see the government as a powerful "special interest" of its own, always potentially inimical to the interests of the governed. Consequently, liberals regard the democratic system of representation (and at the electoral process itself) not as a positive emanation from the sovereign, but as a purely negative device, allowing the voters to cashier a government that they perceive is not doing its job.

Every system of representation involves some form of aggregation of private preferences into a collective choice, but most participants in the drafting process have not clearly observed this

42 Under most systems of proportional representation, the smaller the district, the greater the departures from the principle of proportionality.

4s The canonical text here, is Kenneth Arrow, Social Choice and Individual Values (Yale, $2 \mathrm{~d}$ ed 1963). Arrow's work has generated a whole literature. For a review of later developments, see Russell Hardin, Collective Action (Johns Hopkins, 1982). 
point. In this respect the different electoral systems differ only with respect to the point in time at which the various groups must strike a compromise to produce an effective majority. In the system of proportional representation, this bargain is struck after the elections, when the parties must agree to form a government or pass new legislation. In the majoritarian system, by contrast, the key compromises are made before the election, when various social interests must come together around a party program that can gain a majority of the popular vote. In the majoritarian system, therefore, diverse social interests tend to form two political blocs, each tending toward the center of the political spectrum, ${ }^{44}$ and the election itself tends to become a plebiscite on the fate of the bloc in power.

The system of proportional representation, on the other hand, provides no premium for shaping broad coalition programs. On the contrary, the most rational policy is to form narrowly based parties and enter into coalitions only after elections. ${ }^{45}$ But then the voters can hold no single party to account for the government's policies: each party can still claim to represent the interests of its constituency, and if the government's program does not correspond to the preferences of a party's voters, the party can always attempt to shift the blame to other parties with which it formed a post-election coalition. Consequently, the most important political decisions, namely those that aggregate individual (or group) choices into social policies, are never directly subjected to popular approval. The strong theory of representation underlying proportional representation, affirming the identity of the governors and the governed, thus clashes with the strong theory of governmental responsibility, which allows for direct electoral control of the team in power. ${ }^{46}$

" Assuming that the political spectrum can be represented as a straight line (a controversial assumption) and that the people on both extremes vote (an assumption that is not always justified), each bloc can take for granted the extremes on its side of the spectrum (the right-of-center bloc the extreme right, the left-of-center the extreme left). Consequently, both blocs tend to compete for the votes in the center.

4s Any coalition program must contain points with which any particular interest group will disagree. In a system of proportional representation (especially in its extreme versions), however, there is no premium on achieving any particular percentage of the vote in order to gain representation. Consequently, any time a party adopts a broadly based program and holds on to it for a sufficiently long time, another party is likely to be formed that reflects more closely the views of some section of the first party's constituency and scoops some of its votes.

16 To be sure, the foregoing applies to the rather pure and idealized versions of the two electoral systems. In practice, the systems are often not "pure" and other constraints such as minimum thresholds or the size of districts in proportional representation modify the 
B. The Relationship Between Electoral Law and the Development of Political Parties

Participants in the drafting of the electoral law also had to consider the fact that Poland's transition to democracy did not lead to the quick formation of effective political parties. The need to preserve unity in order to oppose the communists, and later the crushing victory of the Solidarity bloc, gave the politicians centered around the union a near monopoly on political power. The only effective political organization took the form of the so-called Citizens' Committees, a loose alliance of anti-communists hastily formed under the auspices of Solidarity for the purpose of winning the 1989 election. All attempts to transform the Citizens' Committees into a political party ultimately foundered as a result of the personal ambitions of the various contenders for power in Warsaw, and the Committees remained essentially a dominant non-party political machine.

A number of small parties also appeared on the scene, some of which were reincarnations of the political movements from the communist regime, above all the Social Democratic Party, which is a new organization of former communist activists, while others anachronistically harkened back to pre-World War II divisions. Efforts to form new parties, one supporting Walesa and the Gdansk group ${ }^{47}$ the other centered around Prime Minister Mazowiecki and the Warsaw intellectuals, ${ }^{48}$ have failed so far, with the polls showing a very low level of recognition or support for both movements.

In this situation, both proportional and majoritarian systems carry a number of dangers. Proportional representation cannot work without a party system; its adoption could simply mean that the existing parties, including the anachronistic and sterile pre-war ones that would ordinarily disappear with their geriatric leadership, are frozen into the permanent political landscape of Poland. The majoritarian system, on the other hand, can function with a very weak party system by focusing representation around strong political personalities or regional interests. This system might create a situation like that in Mexico, with the domination of the political structure by the political machine of the Citizens' Committees. Alternatively, the majoritarian system might create a

consequences of the electoral rules themselves. But these pure cases help us analyze the tendencies that a given electoral system will exhibit. It is the relative scarcity of such an analysis in the Polish context that I found disturbing.

47 The Center Alliance.

\&8 The Civic Movement-Democratic Action, known by its Polish acronym ROAD. 
caricature of the American Congress, devoid of even the weak American party system. Without the offsetting strength of the presidential office, this could result in legislative paralysis and endemic rent-seeking localism.

Even assuming that a stable party system could emerge in Poland, the proponents of a majoritarian system had yet another worry. To be sure, a two-party system has many virtues in the abstract. It presupposes, however, that the various social interests are able to coalesce into two basic, lasting political groupings, with all the compromises and ideological ambiguities that this process involves. On this score, however, there were good reasons to wonder whether the social structure and the political tradition of Poland could comfortably accommodate a two-party system. Presumably, like every European country, Poland will one day have a party representing the interests of the workers and other social democratic constituencies and another party representing the interests of the large and small owners of capital. Yet many people had great difficulty imagining the Polish political landscape without a powerful peasant party or the complicating factors of nationalism and $\mathrm{Ca}$ tholicism. While most western countries have managed to integrate these interests into basically two-bloc politics, an artificial attempt to accelerate this development in Poland could misfire. For this reason, many opponents of proportional representation advocated the more complex French system, in which the absolute majority requirement in a two-stage electoral process allows for a multiparty system while creating strong incentives to form two-bloc electoral alliances.

\section{The Absence of Electoral Law from the Draft Constitution}

Work on the new electoral law remains incomplete as of this writing. But even a cursory look at further developments shows continuing instability. At one time, the parliamentary leadership was ready to propose a moderately proportional system of representation. ${ }^{49}$ Then a majoritarian system was seriously considered, and a mixed ordinance was actually proposed and extensively debated. A number of competing proposals were presented from the floor, most of them very strongly proportional. But the presidential election intervened, and the work on the parliamentary election

40 Using the d'Hondt method and rather small districts. For an explanation of the d'Hondt system, see Enid Lakeman, How Democracies Vote: A Study of Electoral Systems (Faber, 4th ed 1974). 
law was postponed, to be resumed at the beginning of 1991. This work is still in progress, with the Constitutional Committee and the Presidential Palace putting forth two competing proposals..$^{50}$

Precisely because the discussion of the new electoral law has been rather chaotic, with the moods shifting often in quite opposite directions and opportunistic considerations playing an increasingly important role, some voices demanded that the constitution itself spell out the most basic electoral principles. This would preclude a constantly changing set of rules, in which parties temporarily in control seek to preserve their power by tampering with the electoral laws, and might provide a permanent stimulus to the formation of a broadly supported party system. After some initial momentum, the move to include the basic choice of an electoral system in the constitution lost most of its support. Among the common arguments against it was the unconvincing (and factually inaccurate) claim that few countries have such constitutional provisions. ${ }^{61}$ The more convincing argument was that the Round Table Parliament, containing the communist, epigones committed to proportional representation, would oppose any constitutional provisions mandating a majoritarian system. And since most people who took the idea seriously favored some form of the majoritarian system, attempts to include such a provision were discontinued.

\section{The Parliament, the Government, and the President}

Eastern Europeans have not only a long-standing commitment to democratic institutions, but also an intuitive understanding of democratic procedures that is often surprising in people who lived under dictatorship for fifty years. My favorite example comes from personal experience of many years ago, when I participated in an illegal meeting during the student demonstrations at the University of Warsaw in 1968. I remember vividly my astonishment that

\footnotetext{
${ }^{\text {so }}$ The presidential proposal contains a larger number of single-member districts and a country-wide system of proportional representation for the rest of the seats. The Constitutional Committee's proposal has a smaller number of single-member districts, but limits somewhat more the chances of the smallest parties by having a number of small multimember districts. A minority of the committee proposed to privilege the larger parties still further by the use of a 5 percent threshold and a d'Hondt system of seat assignment.

${ }^{81}$ Among the countries whose constitutions contain such provisions are: Australia, Ch I, Part II, \& 9 (Senate elections); Belgium, Art 48; Canada, Art 40; Greece, Art 54, § 3 (partial); India, Art 80, $\$ 4$ (Upper House); Ireland, Arts 16.2.5, 18.5; Italy, Art 56; Mexico, Art 52; The Netherlands, $\mathrm{Ch} 3$, Arts 53-55; Portugal, Art 155; Sweden, The Instruments of Government $\mathrm{Ch}$ 3, Arts 6-9; and Switzerland, Arts 73, 80. These texts are available in scattered volumes of Blaustein and Flanz, eds, Constitutions of the Countries of the World (cited in note 1).
} 
the meeting, in which several thousand people took part, was run-with practically no supervision on the part of the leaders of the revolt, most of whom had been arrested before the demonstrations began-as if most of the participants had thoroughly studied the Roberts' Rules of Order, even though in fact not one of them had probably ever heard of the famous rule book. I recall thinking that democracy, or at least its procedural aspects, must simply run in the blood of twentieth-century Europeans.

But the Poles and other Eastern Europeans sometimes take certain democratic cliches too literally. The Eastern European intelligentsia's common attitude toward the role of the national legislature in the political life of the country exemplifies this tendency.

\section{A. The Polish Preference for a Powerful Legislature}

I have described already the prevailing Polish ideas concerning the concept of political representation and the resulting view of the relation between the people and their elected representatives. ${ }^{52}$ When applied to the parliament, they usually yield the following reasoning: all legitimate political power flows from the people. The depository and embodiment of the people's own sovereignty is the national legislature, chosen in universal, equal, direct, secret, and proportional elections. Therefore, the parliament, as the most direct representative of the people, reflecting the principal voices of the nation, should be the supreme organ of government and determine the policy of the nation.

Added to this is the extremely widespread view that free and unfettered debate is the essence of all democratic institutions. While this conviction is of course particularly strong with respect to the parliament, it often extends to other collective bodies, such as labor unions, or political parties. One can easily understand this attitude among people who for years endured staged discussions with a predetermined outcome, and who fought hard for the freedom to air their true convictions. ${ }^{53}$ But the result is that the Poles are extremely suspicious of all forms of authority and do not fully appreciate the role that leadership plays in cutting through a multitude of opinions and making necessary decisions. Just as Poles see representation as not really a delegation but a microcosmic reconstitution of the polity at large, they conceive of responsibility

s2 See Part III.B.

ss However, the Polish distaste for authority 'clearly dates back further than the rejection of the communist oppression. The history of Poland is replete with anarchic institutions, such as the famous liberum veto (the requirement of parliamentary unanimity). 
in decisionmaking as a submission to direct and specific authorization (in the literal sense in which the principal himself becomes the author of the agent's actions), rather than as the presence of external controls over an essentially autonomous agent. This means in practice that the Poles often oppose even the most reasonable limitations that the leadership may want to impose on the freedom of debate (and of parliamentary debate in particular), considering such limitations essentially undemocratic.

Combined together, the Poles' attachments to the principle of legislative supremacy and to free debate potentially interfere with the sensible allocation of powers among the branches of government. In structuring the institutional framework of their new democracy, many Poles (along with other Eastern Europeans) are ready to endow their national legislature with all conceivable powers, and to view the government as in need of constant parliamentary authorization. Typically, this yields a significant constituency for such arrangements as a largely unlimited power of the parliamentary deputies to initiate legislation (with no priority given to governmental proposals), their ability to propose amendments to governmental legislation at nearly all stages of the legislative process, the parliament's power to vote no confidence for the government or any particular minister at any time, and the requirement of parliamentary approval for both appointments and dismissals of government officials. ${ }^{54}$ At the same time, little attention is paid to streamlining parliamentary procedure (it is usually left for the parliament's internal rules), and drafters are prone to ignore the party system that is likely to prevail when they consider the structure of the parliament.

What many Eastern Europeans seem to be missing is some hard-nosed and up-to-date political science: the knowledge of how in fact democratic institutions in the West operate on a day-to-day basis and of the practical consequence of particular institutional arrangements. ${ }^{.6}$ It should be easy to see that a bicameral body

st In the fall of 1990 , when Prime Minister Mazowiecki decided to introduce some cabinet changes, Parliament refused to confirm his dismissal of an otherwise nondescript Minister of Telecommunications. The Prime Minister then told the minister to go on an extended vacation, and one of the most important government departments, charged at that time with some of the most difficult decisions concerning the future development of the country, remained without its head for several months.

s5 I am painting here with a broad brush, to be sure. Many people in Eastern Europe are very learned in political and constitutional theory; I met a number of such men and women during my work in Poland. What I am describing here, however, is a widespread view among many important people, including many members of the Constitutional Committee and other influential opinion-makers, whose support for any constitutional solutions chosen by the drafters would be essential for the final adoption of the committee's work. 
composed of 560 members, organized in six or seven political parties, all lacking genuine control over their members, may not be the most appropriate organ to formulate a coherent national policy and supervise its execution-especially in a country facing monumental social, economic, and political problems related to the transition to a market economy, which requires a leadership capable of making effective decisions. Among those Eastern Europeans who recognize this dilemma, many seem to think that all democratic governments simply must operate in this inefficient fashion. What they generally do not realize is that parliaments in the West do not in fact have the all-encompassing powers they want to bestow on their own, and do not, as a rule, participate actively in the formulation of national policy.

Even in those countries in which the rhetoric of parliamentary supremacy still dominates the discourse of national politics, the principle of party discipline, combined with a variety of procedural rules, places the job of formulating the national policy squarely with the executive; the United Kingdom is perhaps the clearest example here. Parliamentary deliberation is thus more reactive than originary. It functions as a highly visible forum for discussion and criticism of governmental policies by the opposition, rather than as a creative mechanism for shaping directives for the government to follow. In practice, proposals put forth by the executive are not genuinely tested in the process of debate. On the contrary, their passage is normally assured in advance by party discipline in the governmental majority. The long-term effect of the open monitoring of the majority's actions, rather than the legislature's ability to contribute to policy formation, determines the parliament's proper role in the democratic process.

\section{B. The Potentially Contradictory Preference for a Strong Presidency}

Since most Poles do not see the role of the parliament in this way, those who observe the often disorganized proceedings of their legislature and the government's occasional inability to control the legislative agenda tend to view these phenomena as a necessary corollary of the parliamentary system, and sometimes fear that anarchy may lie ahead for the still fragile Polish state. They look for a remedy in the creation of a strong office of the president. Unlike the government, which emanates from the parliament and is not 
directly invested with its power by the people, a popularly elected president may constitute a proper counterweight to the Parliament, because he can claim an equally strong link to the source of all legitimate authority.

There is thus a peculiar tension among the Poles, perhaps more than among other Eastern Europeans. A rather anarchic view of democracy, emphasizing the supremacy of undisciplined parliamentary power, coexists with a readiness to support a highly personal embodiment of popular will in the office of a potentially authoritarian president. Discussions surrounding the recent presidential campaign made this duality evident. Lech Walesa gained considerable support for his promise to be a roving people's representative, demanding the power to solve by decree the problems that supposedly clogged the channels of political and economic change. While Walesa presented himself as a problem solver, his opponents depicted him as lacking the slightest understanding or respect for the democratic institutions of his own country. ${ }^{56}$ Much of this debate went beyond the exaggerations characteristic of an election campaign. The people in the Walesa camp sincerely believed that their defeat would bring about governmental paralysis, while many quite sophisticated members of the opposition believed with equal sincerity that a Walesa victory might lead to dictatorship.

\section{The .Draft Constitution: Reconciling the Conflicting Preferences}

In light of this intellectual climate, the Subcommittee on Institutions produced a remarkable proposal, rejecting both a strong presidential office and unfettered parliamentary authority. ${ }^{57}$ Instead, the subcommittee proposed to institute a strong government, capable of imposing discipline on the parliamentary proceedings, with a president functioning as an impartial arbiter, empowered to break impasses at moments of political crisis.

The proposals drafted by the Subcommittee on Institutions emerged from a long and cumbersome process. The subcommittee met frequently during 1990 to discuss the text of various provisions provided by individual experts. Because the sections prepared in this way lacked sufficient unity, and because the subcommittee did not vote to accept or reject any of the drafts presented

\footnotetext{
So The Polish daily press had numerous articles discussing this debate.

sz The text discussed in this section is on file with $U$ Chi $L$ Rev.
} 
to it, a number of members felt somewhat frustrated at the apparently unfocused proceedings. Nevertheless, after a considerable amount of time was spent in this process, those members and experts who took part came to know each other quite well, and bonds of respect and understanding began to develop despite the participants' greatly varying backgrounds and convictions. Then, in the fall of 1990, a smaller group of self-selected experts and a few deputies gathered in a small palace near Warsaw for a number of marathon sessions, during which they agreed upon drafts of the most important sections on the parliament, the government, and the presidency. The full Constitutional Committee later approved this draft with very few changes.

The subcommittee started its final deliberations with the outlines of a broad agreement: the office of the president would not be purely ceremonial, but the president would be neither the chief executive nor a dominant figure on the policymaking scene. Parliament would control the government and provide a public forum for discussing policy matters, but would not become an executive committee of several hundred members. The agenda for the nation and the ability to shape policy would be firmly in the hands of the government.

The main problem facing the subcommittee in the last stages of its work was to translate these principles into the language of concrete constitutional provisions. Above all, the subcommittee had to determine how to confer on the government the powers that would enable it to exercise undisputed leadership in the policymaking area, without undermining its democratic responsibility to the parliament. The task appeared particularly difficult in light of two circumstances: the country did not have an established party system to assure a smooth functioning of the parliament, and (for reasons discussed in Part III) the drafters knew that they could not deal with this problem by imposing a majoritarian electoral system that would foster the formation of strong governmental majorities in the legislature.

The drafters therefore chose to provide a number of lesser measures, each of which would strengthen somewhat the hand of the government, with the hope that together they would provide sufficient leverage for the emergence of a strong governmental leadership. In particular, the drafters attempted to create a series of mechanisms to differentiate strongly between the positions of the supporters and the opponents of the government, as well as produce significant incentives for the deputies, even in the absence of strong party discipline, to toe the line on matters considered important by the government. 
The first device used was to make the government relatively independent of small shifts in parliamentary opinion and capable of riding through moments of dissatisfaction. This goal was achieved, initially, in two ways: first, by making the office of the prime minister dominant in the government and, second, by making it very difficult to remove the government from power without a broad consensus. The drafters intended, in other words, to shift the burden of parliamentary inertia (which may become very considerable in a body with many weakly organized parties) from the government to the opposition, thus making the same forces that potentially contribute to chaos work in favor of the constituted authority.

The predominance of the prime minister was assured in several ways. To begin with, the president-not the legislature-was to designate the prime minister. Where an already constituted majority existed in parliament, the president would have little choice but to designate its leader, because the parliament could twice reject the president's candidates and then designate a prime minister of its own choice. When parliament did not have a clear candidate of its own, however, the support of the head of state would considerably strengthen the new prime minister. Not only would the nomination confer on him a degree of nonpartisan prestige, but the president and the prime minister, acting together, would enjoy considerable powers. The most important of these would be the president's ability to dissolve parliament upon the failure of a vote of confidence that the prime minister could request in connection with significant legislative proposals of the government. ${ }^{58}$

The prime minister would be further strengthened by his dominant position among the ministers. The presidential designee would be empowered to choose his government, which would be submitted for parliament's approval as a unit. Any minister could then be dismissed by the prime minister acting alone, ${ }^{59}$ and parliament would have no power to remove any of the ministers, without bringing down the government as a whole. The draft also clearly gives the prime minister a leading role in the government and

ss Parliament could avoid dissolution in such cases only by voting the confidence requested, or transforming the vote of confidence into a constructive no confidence vote as explained below. The failure of a vote of confidence would not by itself lead to the government's resignation, even if the parliament were not dissolved.

s9 When dismissing a minister, the prime minister would be obliged to inform the Sejm and explain his decision. Any new minister would have to be confirmed by the Sejm. 
makes him the official superior of every member of the state administration.

To entrench the position of the government, the draft makes it removable by parliament only through the procedure of the socalled "constructive no confidence," borrowed from the Federal Republic of Germany. ${ }^{60}$ According to this procedure (to be distinguished from the "confidence vote" discussed earlier, which only the government could initiate), parliament can remove the government from office only by designating a new prime minister and voting him in by a majority of all votes, following a seven-day cooling period. ${ }^{61}$

The draft also gives the government a number of other tools intended to strengthen its stability and freedom to maneuver. It facilitates its legislative agenda, by giving priority to governmental legislative initiatives and prohibiting amendments from the floor to its legislative proposals (amendments brought in committees are allowed). Furthermore, it allows the president to dissolve parliament if the budget is not, passed within three months from its submission by the government. If parliament is not dissolved, the government may spend according to its proposed budget; if the budget is not passed within six months, dissolution is automatic. Finally, any proposed amendment to the budget, as well as any other legislation proposed from the floor that involves increased expenditures, must indicate the revenue sources for these expenditures.

Having assured the government a large degree of independence, the draft proceeds to vest parliament with a series of tools to exercise its supervisory functions. It requires the government to provide, within three days, oral explanations on the floor concerning any questions from the deputies, and to provide within 21 days a written answer to any parliamentary requests for information. A special parliamentary body is charged with watching over the administration's accounts and investigating financial abuses. Parliamentary commissions are given wide powers of inquiry, with a right to call all government officials before them.

The system proposed by the draft of the Subcommittee on Institutions makes it clear that the policy of the nation is determined by the government. Consequently, while it allows the president, if he believes a law passed by parliament to be unconstitutional, to

8 Basic Law of Germany Art 67, reprinted in Flanz, The Federal Republic of Germany 62, in Blaustein and Flanz, eds, Constitutions of the Countries of the World (cited in note 1).

a1 A motion by sixty deputies is required to put a no-confidence matter on the agenda. 
submit it to the Constitutional Tribunal prior to his signature, the draft does not give the president the power of legislative initiative, and requires a countersignature of the prime minister in connection with most exercises of the president's authority.

Although the draft thus generally tends to make the president a guardian of the constitutional order, rather than a political figure, there are some aspects of the presidential power in which the subcommittee departed from its vision. The most important of these was the conferral on the president of the veto power, subject to being overridden by a two-thirds vote of the Sejm. A result of instructions from the Constitutional Committee, this concession does create a potential for an increase in the president's power that might undermine the institutional structure the drafters attempted to establish, especially if the ratifiers choose (as proposed in one of the two variants of the draft) to make the president popularly elected. Generally speaking, the chapter dealing with the president was the most difficult for the subcommittee; the pressure of events leading to the presidential election of 1990 , could be felt throughout the final stages of the subcommittee's deliberations.

\section{CoNCLUSION}

The work on the new constitution of the Polish Republic is not yet complete, and it is not clear to what extent the present draft will be retained by the next Parliament (to be elected in October 1991), which will have the ultimate responsibility for enacting the new basic law. But the experience of the drafting brings to the fore the most fundamental problem facing the constitution makers of Eastern Europe: the fact that the new constitution must be prepared at a time of profound and rapid changes in the political and economic structure of the country. These changes reveal, among other things, that the broad consensus among the members of the erstwhile opposition to the communist dictatorship tends to disintegrate rather quickly, once the enemy has been defeated. This consensus was not shallow, insofar as it expressed a shared commitment to the most fundamental values of personal liberty and political democracy. But precisely because the consensus was very broad and opposition to the communists did not require the elaboration of a more concrete conception of democracy and its institutions, those opposed to the communists never developed a unified vision of the institutional arrangements which must now replace the old dictatorship. Consequently, Poland, like the other countries of Eastern Europe, is in part drifting into a new political structure. The lack of clear models to follow and the absence of 
experience in designing practical solutions to the basic problems of the polity make the efforts to establish the new constitutional order both exhilarating and fraught with danger. Perhaps the most interesting question in this regard is to what extent the people involved in this process will be able to control it, and to what extent the events of the moment will obscure a vision of the more distant future. 
